\title{
GIP-induced vasodilation in human adipose tissue involves capillary recruitment
}

\author{
Meena Asmar ${ }^{1,2}$, Ali Asmar ${ }^{2,3}$, Lene Simonsen², Flemming Dela ${ }^{4,5}$, Jens Juul Holst ${ }^{6,7}$ and Jens Bülow ${ }^{2,7}$ \\ 'Department of Endocrinology, Bispebjerg and Frederiksberg Hospital, University Hospital of Copenhagen, Copenhagen, Denmark \\ 2Department of Clinical Physiology and Nuclear Medicine, Bispebjerg and Frederiksberg Hospital, University Hospital of Copenhagen, \\ Copenhagen, Denmark \\ ${ }^{3}$ Department of Clinical Physiology, Nuclear Medicine and PET, Rigshospitalet, University Hospital of Copenhagen, Copenhagen, Denmark \\ ${ }^{4}$ Xlab, Center for Healthy Ageing, University of Copenhagen, Copenhagen, Denmark \\ ${ }^{5}$ Department of Geriatrics, Bispebjerg and Frederiksberg Hospital, University Hospital of Copenhagen, Copenhagen, Denmark \\ ${ }^{6}$ NNF Center for Basic Metabolic Research, University of Copenhagen, Copenhagen, Denmark \\ ${ }^{7}$ Department of Biomedical Sciences, University of Copenhagen, Copenhagen, Denmark
}

Correspondence should be addressed to M Asmar: meenaasmar@outlook.dk

\begin{abstract}
Glucose-dependent insulinotropic polypeptide (GIP) in combination with hyperinsulinemia increase blood flow and triglyceride clearance in subcutaneous abdominal adipose tissue in lean humans. The present experiments were performed to determine whether the increase involves capillary recruitment. Eight lean healthy volunteers were studied before and after $1 \mathrm{~h}$ infusion of GIP or saline during a hyperglycemic-hyperinsulinemic clamp, raising plasma glucose and insulin to postprandial levels. Subcutaneous abdominal adipose tissue blood flow (ATBF) was measured by the ${ }^{133}$ Xenon clearance technique, and

\section{Key Words}

- glucose dependent insulinotropic polypeptide

- adipose tissue

- blood flow

- ultrasonic imaging

- microcirculation microvascular blood volume was determined by contrast-enhanced ultrasound imaging. During infusion of saline and the clamp, both ATBF $(2.7 \pm 0.5 \mathrm{~mL} / \mathrm{min} 100 \mathrm{~g} / \mathrm{tissue})$ and microvascular blood volume remained unchanged throughout the experiments. During GIP infusion and the clamp, ATBF increased fourfold to $11.4 \pm 1.9 \mathrm{~mL} / \mathrm{min} 100 \mathrm{~g} /$ tissue, $P<0.001$. Likewise, the contrast-enhanced ultrasound signal intensity, a measure of the microvascular blood volume, increased significantly $1 \mathrm{~h}$ after infusion of GIP and the clamp $(P=0.003)$, but not in the control experiments. In conclusion, the increase in ATBF during GIP infusion involves recruitment of capillaries in healthy lean subjects, which probably increases the interaction of circulating lipoproteins with lipoprotein lipase, thus promoting adipose tissue lipid uptake.

\section{Introduction}

The regulation of subcutaneous adipose tissue blood flow (ATBF) is crucial in lipid homeostasis $(1,2)$. It has long been recognized that the ATBF is tightly coupled to adipose tissue metabolism $(3,4,5,6)$. In response to feeding, an increase in ATBF is seen in healthy subjects (4). GIP is involved in the increase of ATBF in healthy subjects $(7,8$, 9). GIP is a polypeptide hormone that is secreted from the small-intestinal $\mathrm{K}$ cells in response to nutrient intake (10). GIP is well founded as an incretin hormone potentiating insulin release from $\beta$-cells in healthy humans $(10,11,12)$.
In addition to its insulinotropic effects, we have previously shown that GIP infusion during physiological hyperglycemia and hyperinsulinemia increases ATBF and stimulates glucose uptake and triacylglycerol (TAG) deposition in adipose tissue in lean humans (7). In contrast, in these experiments neither GIP nor hyperinsulinemia per se had any effect on ATBF. Subsequent studies in lean healthy subjects demonstrated that insulin is essential for GIP to increase ATBF and adipose tissue TAG clearance (9). In obese humans with impaired glucose tolerance, (c) 2019 The authors Published by Bioscientifica Ltd
This work is licensed under a Creative Commons Attribution-NonCommercial-NoDerivatives 4.0 Internationab ticense.ifica.com at 04/26/2023 01:31:29PM 
GIP infusion in combination with hyperglycemia and hyperinsulinemia did not induce any changes in ATBF and TAG uptake in adipose tissue (13). However, weight loss (mean weight loss: $7.5 \mathrm{~kg}$ ) induced by caloric restriction in obese humans with impaired glucose tolerance, resulted in improved insulin sensitivity and partly restored the vasodilatory effect of GIP and insulin during otherwise comparable experimental conditions (8). Recently, we demonstrated that the circulatory and metabolic effects of GIP in adipose tissue can be blocked by a truncated form of human GIP, GIP (3-30)NH2, which is a high-affinity competitive antagonist of the human GIP receptor (14). In addition, we have previously shown that in subcutaneous abdominal adipose tissue of healthy lean subjects, there is an increased capillary recruitment in response to an oral glucose load, as indicated by an increased microvascular blood volume (15). The recruitment of capillaries will expose a larger amount of the circulating triacylglycerol particles to the endothelial lipoprotein lipase (LPL), increasing the hydrolysis of these particles. This, in turn, will give rise to an enhanced free fatty uptake in adipose tissue. Thus, the aim of this study was to elucidate whether the effects of GIP on ATBF and lipid metabolism involves capillary recruitment in healthy lean subjects.

\section{Materials and methods}

\section{Subjects}

Eight healthy non-smoking males were studied. The anthropometric characteristics, subcutaneous adipose tissue thickness, body fat composition, lipid and glucose profile are summarized in Table 1. The subjects also took part in a recent, reported study (14). None of the subjects had a positive family history of diabetes. All had normal fasting blood concentrations of glucose,

Table 1 Anthropometric characteristic, lipid and glucose profile of studied male subjects.

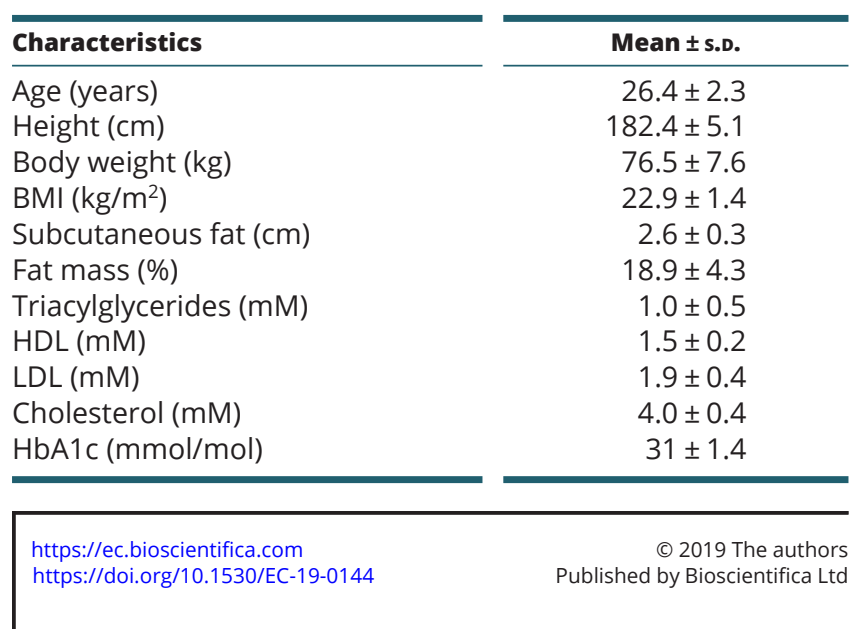

lipids and hemoglobin and normal renal and hepatic functions. All subjects gave informed written consent to participate. The protocol was approved by the Ethical Committee of Copenhagen Municipality (H-2-2010-079), and the study was performed in accordance with the Helsinki Declaration II.

\section{Experimental design}

The study protocol had a cross-over design with a washout period of at least 2 weeks. Each subject served as his own control and was studied, in a randomized order, on two different occasions during infusion of GIP $(1.5 \mathrm{pmol} / \mathrm{kg} / \mathrm{min})$ or saline during $60 \mathrm{~min}$ - both days in combination with physiological hyperglycemichyperinsulinemic $\left(\mathrm{Hy}_{\text {gluc }}-\mathrm{Hy}_{\text {ins }}\right)$ clamps, raising plasma glucose and insulin to postprandial levels.

\section{Protocol}

The subjects were instructed to abstain from drinking alcohol or doing strenuous physical activities for 2 days prior to the experiments to ensure equally filled glycogen stores. On the days of the experiments, subjects arrived at the department at 08:00 h having used non-strenuous transportation and after having fasted for at least $12 \mathrm{~h}$. The investigations were performed with the subjects in supine position in a room kept at $24^{\circ} \mathrm{C}$. A catheter (BD Venflon, TMPRO, Becton Dickinson, Singapore) was inserted into an antecubital vein for the infusion of GIP, saline, glucose, insulin and SonoVue (see below).

After baseline measurements (time $-30,-15$ and 0 min) a continuous infusion of either GIP or saline in combination with the clamp were commenced.

\section{GIP infusions and the clamp}

GIP

Synthetic human GIP (1-42) was purchased from Bachem (Bubendorf, Switzerland) and demonstrated to be $>97 \%$ pure and identical to the natural human peptide by HPLC, mass and sequence analysis. GIP was dissolved in saline containing 0.5\% human serum albumin (Human Albumin, CSL Behring, Marburg, Germany) and subjected to sterile filtration.

\section{$\mathrm{Hy}_{\text {gluc }}-\mathrm{Hy}_{\text {ins }}$ clamp}

The objective of the $\mathrm{Hy}_{\text {gluc }}-\mathrm{Hy}_{\text {ins }}$ clamp was to increase plasma glucose levels above fasting levels $(6.5-7 \mathrm{mM})$ and

This work is licensed under a Creative Commons Attribution-NonCommercial-NoDerivatives 4.0 Internationab ticense.ifica com at 04/26/2023 01:31:29PM 
to increase insulin concentration to postprandial levels. The protocol included: (1) a continuous, variable glucose infusion (the infusion rate was adjusted every 5-10 min according to measured plasma glucose to maintain the glucose concentration at the desired target); and (2) during saline infusion, insulin (Actrapid Human; Novo Nordisk) was infused at a continuous rate of $10 \mathrm{mU} / \mathrm{m}^{2} / \mathrm{min}$. During concomitant GIP infusion, insulin infusion rate was adjusted according to the expected endogenous insulin secretion in response to GIP aiming toward plasma insulin levels comparable to those obtained during insulin infusion alone. Therefore, insulin was infused at a lower rate $7 \mathrm{mU} / \mathrm{m}^{2} / \mathrm{min}$ under these conditions.

\section{Contrast-enhanced ultrasound imaging and image analysis}

Contrast-enhanced ultrasound imaging has previously been validated in our laboratory and is a reliable method to estimate the microvascular blood volume in human subcutaneous abdominal adipose tissue (15). An ultrasound transducer was placed vertically and each time at the same side of the abdomen approximately $5 \mathrm{~cm}$ above the iliac crest and at the para-umbilical area in the mid-clavicular line. The location of the transducer was highlighted before the infusions were started; thus, it was possible to use the same location later $(1 \mathrm{~h}$ after the start of infusions). The transducer was held in a fixed position and the subjects were instructed not to change body position during the measurements. At baseline and $1 \mathrm{~h}$ after GIP or saline infusion, a bolus of $2.5 \mathrm{~mL}$ of the ultrasound contrast agent (SonoVue Bracco S.p.A, Milan, Italy) was injected intravenously followed by an immediate flush of $10 \mathrm{~mL} 0.9 \%$ saline solution. SonoVue is a suspension of phospholipid-stabilized microbubbles filled with hexafluoride; it is diluted with $4.5 \mathrm{~mL} 0.9 \%$ saline solution before injection $(8 \mu \mathrm{L}$ microbubbles $/ \mathrm{mL})$. Ultrasound scanning was performed using a linear array transducer (L9-3 MHz) and an iU22 ultrasound scanner (Phillips Medical Systems, Bothell, WA, USA). B-mode imaging is created from broadband spectra of acoustic frequencies from 3 to $9 \mathrm{MHz}$. Contrast first harmonic signals were received at $8 \mathrm{MHz}$ with mechanical index of 0.06 . The depth was set at $3 \mathrm{~cm}$ allowing for measurements in subcutaneous abdominal adipose tissue. Focus and gain were optimized at the beginning of the experiment and held constant throughout. Twenty millisecond images were captured consecutively for $2 \mathrm{~min}$ after each bolus injection.
Image analysis was performed off-line using an ultrasound quantification and analysis software (QLAB version 7; Phillips Medical Systems). The analysis consisted of examination of region of interest (ROI) for each recording in the subcutaneous abdominal adipose tissue. The ROI placements were in areas that excluded larger vessels during the enhancement phase. In a ROI, the relative microvascular blood volume expressed in $\Delta$ decibels (dB) in the tissue was determined as the mean signal intensity in $\mathrm{dB}$ during the first plateau phase after subtraction of the mean signal intensity registered immediately before the contrast bolus injection, Fig. 1 (16).

\section{Determination of ATBF}

ATBF in the subcutaneous abdominal adipose tissue contralateral to the ultrasound transducer position was determined during the whole experiment by recording washout of ${ }^{133}$ Xenon, which was injected in gaseous form into the adipose tissue. This technique has previously been validated in our laboratory (17). About $1 \mathrm{MBq}$ gaseous ${ }^{133}$ Xenon mixed in about $0.1 \mathrm{~mL}$ of atmospheric air was injected into the para-umbilical area of the subcutaneous abdominal adipose tissue. The washout rate of ${ }^{133}$ Xenon was measured continuously by a scintillation counting device placed over the exact site of injection and fixed firmly in place (Mediscint, Oakfield Instruments, Oxford, UK). The ATBF was calculated from the mean washout rate constant determined in $30 \mathrm{~min}$ periods corresponding to the time points when blood samples were drawn. A tissue/blood partition coefficient for ${ }^{133}$ Xenon of $10 \mathrm{~mL} / \mathrm{g}$ was used. In order to detect early flow changes, a monoexponential curve was fitted to the washout curve registered in the basal control period

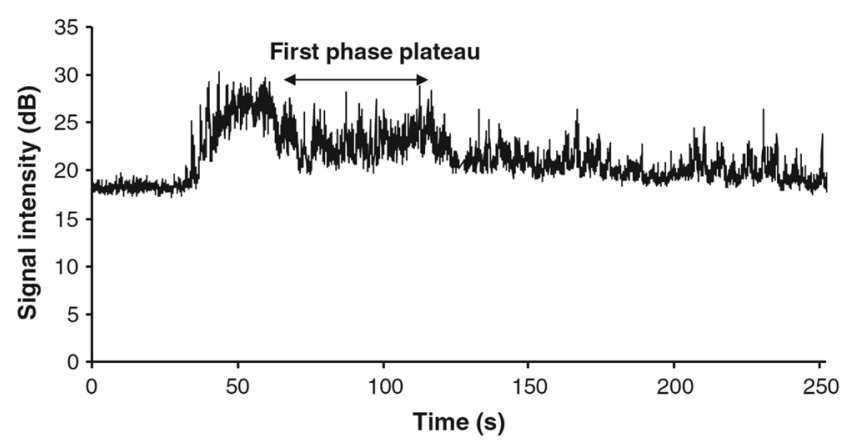

Figure 1

A curve from the subcutaneous abdominal adipose tissue after administration of a bolus of the ultrasound agent SonoVue ${ }^{\circledR}$ in one subject. The first-phase plateau level is used for the calculation of the microvascular blood volume.

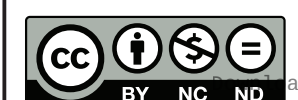

This work is licensed under a Creative Commons Attribution-NonCommercial-NoDerivatives 4.0 Internationab bicense.ifica. com at 04/26/2023 01:31:29PM 
immediately before the hormone infusions were initiated. The commencement of the vascular effects was defined when the slope of the ${ }^{133}$ Xenon-washout curve deviated from the baseline slope by visual inspection.

\section{Blood samples}

Arterial blood samples were drawn at times -30, -15, 0, 30 and $60 \mathrm{~min}$. Blood samples were collected in iced chilled tubes (Vacuetta; Greiner Labortechnic, Kremsmünster, Austria) from the artery for measurements of GIP and insulin. Tubes for total GIP contained EDTA and tubes for insulin contained heparin. All samples were centrifuged within $15 \mathrm{~min}$ for $15 \mathrm{~min}$ at $5000 \mathrm{~g}$ at $4^{\circ} \mathrm{C}$ and stored at $-80^{\circ} \mathrm{C}$ until analysis.

\section{Blood analysis}

Total plasma GIP concentrations were measured using a C-terminally directed antibody (18). Plasma insulin concentrations were measured by auto-DELPHIA automatic fluoroimmunoassay (14). Plasma glucose concentrations were measured bedside during the clamp experiments, using the Radiometer ABL 725 blood gas analyzer (Radiometer Corp., Brønshøj, Denmark).

\section{Calculations and statistical analysis}

The ATBF was calculated from the mean washout rate constant determined in 30-min periods corresponding to the time points when blood samples were drawn. ATBF was then calculated according to the equation $\mathrm{ATBF}=-\mathrm{k} \times \lambda \times 100$, where $\mathrm{k}$ is the washout constant and $\lambda$ is the tissue/blood partition coefficient $(\lambda)$ for ${ }^{133}$ Xenon.

Sample size was determined before the study using power analysis $(P=0.8, \alpha=0.05)$ with regard to ATBF responses based on our previous publications $(7,8,9,13$, 14). Assuming an ATBF response as found previously in normal weight, healthy subjects, less than six subjects were needed in the present study.

All results are presented as mean \pm s.E.M. The significance of changes in ATBF with time was evaluated using two-way ANOVA for repeated measures. Changes in ultrasound signal intensity from baseline during GIP and saline infusions were compared, using paired $t$ test (two-tailed). $P$ values of $<0.05$ were considered statistically significant. The Spearman correlation test was used to calculate the correlation between ATBF and microvascular blood volume.
Data were analyzed using GraphPad Prism 8 (GraphPad Software, Inc., La Jolla, CA, USA).

\section{Results}

\section{Arterial glucose, insulin and GIP concentrations}

Figure 2 shows plasma glucose, insulin and total GIP concentrations during GIP and saline. The concentrations of glucose, insulin, GIP during infusion of GIP have been a part of our recently published study (14), however, in the present study, besides baseline concentrations, only the concentrations during the first hour after commencement of GIP infusion and the clamps are shown and described, corresponding to the time capillary recruitment was measured. The clamps were carried out successfully. Plasma glucose levels reached the target levels of $6.8 \pm 0.1$ and $6.9 \pm 0.1 \mathrm{mM} 30 \mathrm{~min}$ after start of the infusion of GIP and saline, respectively, Fig. 2A. There was no significant difference between the amounts of glucose infused during these two experiments $(27 \pm 5$ and $17 \pm 3 \mathrm{~g}$, $P=0.2$ ), reflecting similar insulin levels during the two experiments. Plasma insulin levels increased significantly and reached levels of $404 \pm 8$ and $358 \pm 15 \mathrm{pM} 30 \mathrm{~min}$ after the start of infusion of GIP and saline, respectively, Fig. $2 \mathrm{~B}, \mathrm{P}=0.1$.

During GIP infusion, total plasma GIP concentrations increased significantly from fasting levels $(9.9 \pm 0.3 \mathrm{pM})$ and after approximately $30 \mathrm{~min}$ reached mean plateau levels of $120 \pm 7 \mathrm{pM}$, whereas plasma GIP levels remained unchanged and at fasting levels during saline infusion (8.1 \pm 0.9 pM), (Fig. 2C).

\section{Changes in subcutaneous abdominal ATBF}

Figure 3 shows the subcutaneous abdominal ATBF during the two experiments. Baseline ATBF did not differ between the two studies $(2.6 \pm 0.6$ and $2.5 \pm 0.5 \mathrm{~mL} / 100 \mathrm{~g} / \mathrm{min})$ ). ATBF during GIP infusion has been described in our recent study (14) but in the present study only ATBF during the first hour after commencement of infusion of GIP and the clamps are shown and described. During GIP infusion ATBF increased fourfold to a mean level of $11.4 \pm 1.9 \mathrm{~mL} / 100 \mathrm{~g} / \mathrm{min}$ $(P=0.004)$, whereas ATBF remained unchanged during saline infusion $(2.7 \pm 0.5 \mathrm{~mL} / 100 \mathrm{~g} / \mathrm{min})$.

\section{Changes in microvascular blood volume}

During the two experiments, baseline $\Delta \mathrm{dB}$ signal intensities were almost similar $(2.1 \pm 0.3$ and $1.5 \pm 0.3 \mathrm{~dB}$,

This work is licensed under a Creative Commons Attribution-NonCommercial-NoDerivatives 4.0 enternationab ticense.ifica.com at 04/26/2023 01:31:29PM 

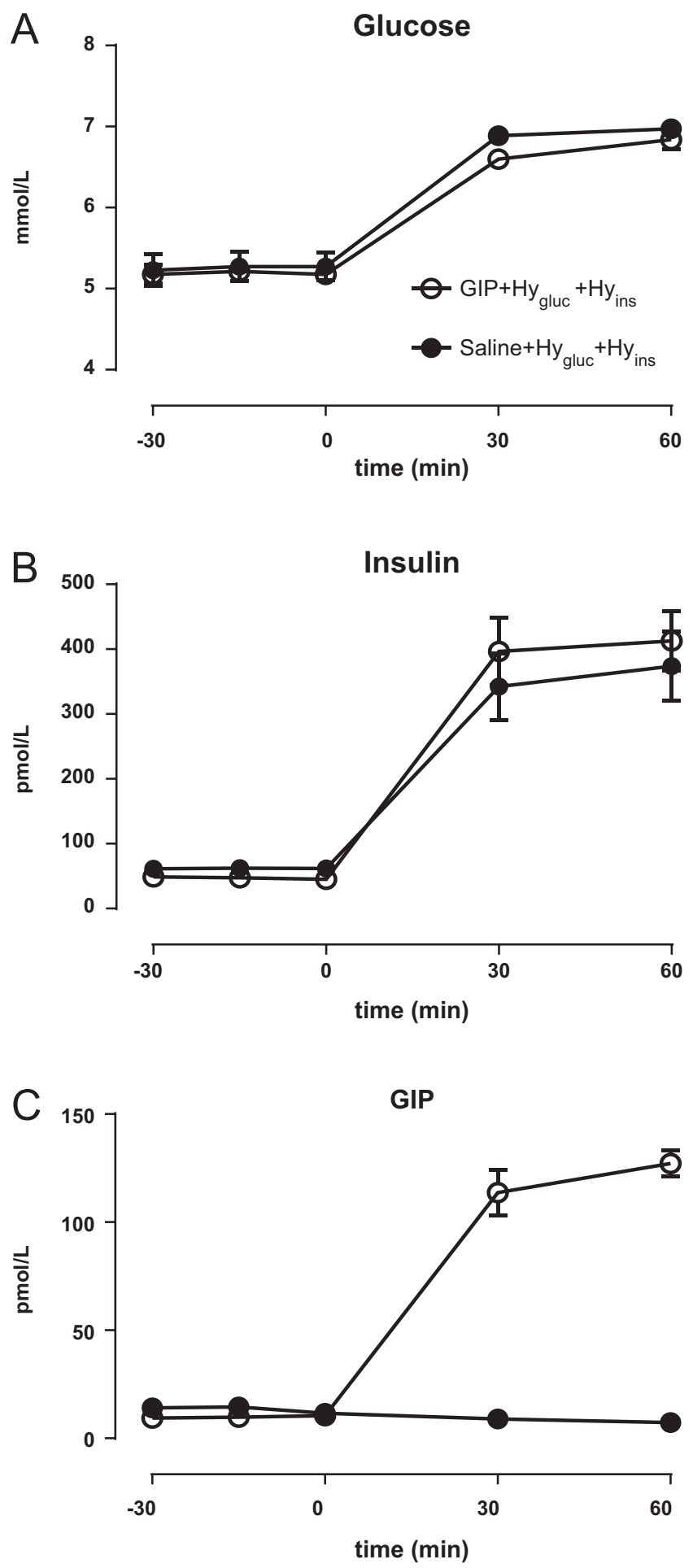

Figure 2

Plasma glucose (A), insulin (B) and GIP (C) concentrations during $\mathrm{Hy}_{\text {gluc }}-\mathrm{Hy}_{\text {ins }}$ clamp with GIP infusion (open circle) and saline (solid circle). Data are mean \pm S.E.M.

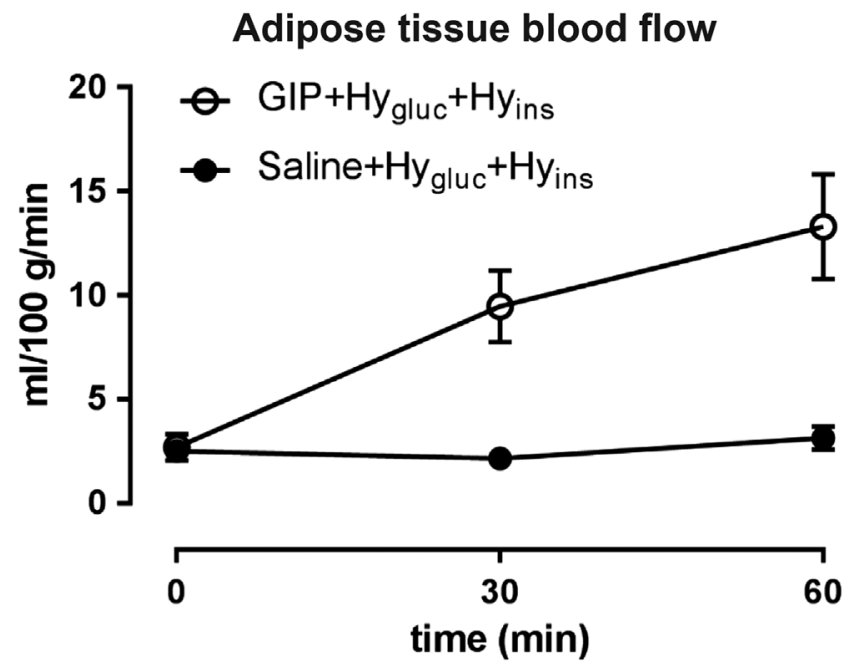

Figure 3

Subcutaneous abdominal adipose tissue blood flow during $\mathrm{Hy}_{\text {gluc }}-\mathrm{Hy}_{\text {ins }}$ clamp with GIP infusion (open circle) or saline (solid circle). Data are

mean \pm S.E.M.

respectively, $P=\mathrm{NS}$, Fig. $4 \mathrm{~A}$ and $\mathrm{B})$. After $60 \mathrm{~min}$ of GIP infusion, the $\triangle \mathrm{dB}$ signal intensity increased significantly (3.6 $\pm 0.4 \mathrm{~dB}$ Fig. $4 \mathrm{~A}, P=0.003)$, whereas no change was seen in the saline study $(1.6 \pm 0.2 \mathrm{~dB}$, Fig. 4B).

There was a significant correlation between microvascular blood volume and ATBF during GIP $(r=0.85$ and $P=0.01)$. No correlation was seen during saline ( $r=0.34$ and $P=0.5$ )

\section{Discussion}

ATBF has a fundamental role in the regulation of the adipose tissue metabolism (4). We have previously shown in several studies that infusion of GIP in combination with insulin increase ATBF up to fivefold $(7,9,14)$. In line with these findings we now show that the increase in ATBF during GIP and insulin plasma levels identical to those reached postprandially involves capillary recruitment. The phenomenon, capillary recruitment, has long been recognized in the skeletal muscle $(19,20,21)$. Few studies have suggested that adipose tissue possesses the ability of capillary recruitment $(15,22)$. However, in the postprandial period, adipose tissue metabolism is, at least in part, dependent on increase in the macrovascular and microvascular perfusion rate (23). The increase in blood flow in adipose tissue following feeding parallels that of plasma GIP and insulin concentrations (24). 

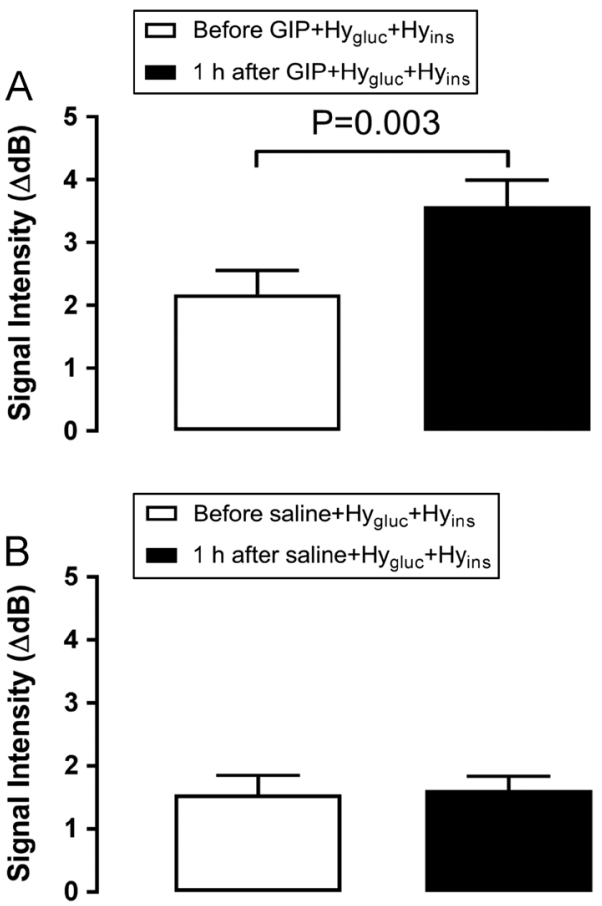

Figure 4

Signal intensity changes from baseline to first-phase plateau $(\Delta \mathrm{dB})$ in subcutaneous abdominal adipose tissue before and $1 \mathrm{~h}$ after $\mathrm{Hy}_{\text {gluc }}-\mathrm{Hy} \mathrm{y}_{\text {ins }}$ clamp with (A) GIP and (B) saline.

Several mechanisms influence the regulation of the postprandial ATBF in humans (23). In humans, adrenergic mechanisms are dominating, with $\beta_{1}$-receptormediated vasodilatation $(3,6)$ and $\alpha_{2}$-receptor-mediated vasoconstriction being the main regulators (25). The blood flow response to feeding is blocked by propranolol infusion (completely in some adipose tissue depots and partially in others) (6), suggesting that it is dependent upon sympathetic activation. The mechanisms behind the induction of the capillary recruitment in the adipose tissues are yet unknown, but a study from our laboratory showed that infusion of adrenaline increased both ATBF and capillary recruitment (26).

In human and animal studies, insulin exerts vascular actions in skeletal muscle, increasing blood flow and glucose disposal $(27,28)$. It recruits microvasculature in the muscle by relaxing terminal arterioles thereby expanding the microvascular blood flow $(20,21,29)$. Furthermore, insulin induces relaxation of resistance vessels and causes an increase of overall blood flow $(27,30)$. The insulininduced microvascular recruitment in muscle is mainly mediated by nitric oxide (NO) (31). NO exerts a major role in vascular biology by regulating vascular tone and mediating vasodilation (32). The same pathway may also be relevant for GIP's action in the adipose tissue microvasculature, as the GIP-induced vasodilatory actions appear to be mediated via endothelium-dependent NO production (33). In the present study hyperinsulinemia per se did not have any effect on neither the ATBF nor the adipose tissue microvascular blood volume. These findings are in accordance with our previous studies in which we found that neither insulin nor GIP per se had any effect on ATBF but that GIP in the presence of insulin above a certain concentration increased ATBF and adipose tissue TAG deposition (7). Administration of even larger amounts of insulin did not elicit further increase in ATBF indicating that insulin exerts a permissive but not additive role for the vasodilatory effect of GIP (9). This effect of GIP is most likely receptor mediated as it can be abolished when antagonizing the human GIP receptor (14). GIP receptors are found also in human adipose tissue (34) and recent studies indicate that GIP receptor expression in subcutaneous adipose tissue is inversely associated with BMI $(35,36)$.

Interestingly, the other incretin hormone, glucagonlike-peptide-1 (GLP-1), also increases total blood flow in adipose tissue in healthy subjects, however, with a delay compared to the effect of GIP (37). Furthermore, GLP-1 has been shown to increase microvascular recruitment in human and rat muscle (38). Whether GLP-1 also increases microvascular recruitment in adipose tissue remains to be elucidated.

In the postprandial state, the adipose tissue's metabolic role is primarily to deposit circulating triglycerides (1). As the enzyme LPL is bound to the adipose tissue capillaries, the capillary recruitment, that is enlarged vascular surface area in the adipose tissue will increase the exposure of the circulating lipoproteins to the enzyme and lead to a postprandial increased lipid deposition in the adipose tissue, at least in healthy subjects (1). This coupled with our previous findings $(7,9,14)$, where we found an increase in TAG hydrolysis, FFA re-esterification and glucose uptake, is consistent with a coordinated GIP response in adipose tissue resulting in increased TAG deposition in subcutaneous abdominal adipose tissue via the conversion of glucose to alpha-glycerol-phosphate to esterify the free fatty acids derived from the TAG hydrolysis.

In conclusion, subcutaneous adipose tissue capillaries are recruited simultaneously with increased ATBF in response to GIP with insulin in healthy lean subjects, thus increasing the exposure of LPL to its substrate.
This work is licensed under a Creative Commons Attribution-NonCommercial-NoDerivatives 4.0 elnternationab sicense.ifica.com at 04/26/2023 01:31:29PM 


\section{Declaration of interest}

The authors declare that there is no conflict of interest that could be perceived as prejudicing the impartiality of the research reported.

\section{Funding}

This research did not receive any specific grant from any funding agency in the public, commercial or not-for-profit sector.

\section{Author contribution statement}

M A designed the study, recruited the subjects, supervised the studies, collected and analyzed the data and wrote the manuscript. A A recruited the subjects, supervised the studies, collected and analyzed the data and reviewed and edited the manuscript. L S supervised the studies, reviewed and edited the manuscript. F D analyzed the samples and reviewed the manuscript. J J $\mathrm{H}$ analyzed the samples and reviewed the manuscript. J B designed the study, supervised the studies, reviewed and edited the manuscript.

\section{Acknowledgements}

The technical assistance of Bente Matthiesen is gratefully acknowledged.

\section{References}

1 Frayn KN. Adipose tissue as a buffer for daily lipid flux. Diabetologia 200245 1201-1210. (https://doi.org/10.1007/s00125-002-0873-y)

2 Samra JS, Simpson EJ, Clark ML, Forster CD, Humphreys SM, Macdonald IA \& Frayn KN. Effects of epinephrine infusion on adipose tissue: interactions between blood flow and lipid metabolism. American Journal of Physiology 1996271 E834-E839. (https://doi.org/10.1152/ajpendo.1996.271.5.E834)

3 Ardilouze JL, Fielding BA, Currie JM, Frayn KN \& Karpe F. Nitric oxide and beta-adrenergic stimulation are major regulators of preprandial and postprandial subcutaneous adipose tissue blood flow in humans. Circulation 2004109 47-52. (https://doi.org/10.1161/01. CIR.0000105681.70455.73)

4 Frayn KN \& Karpe F. Regulation of human subcutaneous adipose tissue blood flow. International Journal of Obesity 201438 1019-1026.

5 Patel JN, Eisenhofer G, Coppack SW \& Miles JM. Norepinephrine spillover in forearm and subcutaneous adipose tissue before and after eating. Journal of Clinical Endocrinology and Metabolism 199984 2815-2819. (https://doi.org/10.1210/jcem.84.8.5882)

6 Simonsen L, Bulow J, Astrup A, Madsen J \& Christensen NJ. Dietinduced changes in subcutaneous adipose tissue blood flow in man: effect of beta-adrenoceptor inhibition. Acta Physiologica Scandinavica 1990139 341-346. (https://doi.org/10.1111/j.1748-1716.1990. tb08932.x)

7 Asmar M, Simonsen L, Madsbad S, Stallknecht B, Holst JJ \& Bulow J. Glucose-dependent insulinotropic polypeptide may enhance fatty acid re-esterification in subcutaneous abdominal adipose tissue in lean humans. Diabetes 201059 2160-2163. (https://doi.org/10.2337/ db10-0098)

8 Asmar M, Arngrim N, Simonsen L, Asmar A, Nordby P, Holst JJ \& Bulow J. The blunted effect of glucose-dependent insulinotropic polypeptide in subcutaneous abdominal adipose tissue in obese subjects is partly reversed by weight loss. Nutrition and Diabetes 2016 6 e208. (https://doi.org/10.1038/nutd.2016.15)

9 Asmar M, Simonsen L, Asmar A, Holst JJ, Dela F \& Bulow J. Insulin plays a permissive role for the vasoactive effect of GIP regulating adipose tissue metabolism in humans. Journal of Clinical
Endocrinology and Metabolism 2016101 3155-3162. (https://doi. org/10.1210/jc.2016-1933)

10 Asmar M \& Holst JJ. Glucagon-like peptide 1 and glucose-dependent insulinotropic polypeptide: new advances. Current Opinion in Endocrinology, Diabetes and Obesity 201017 57-62. (https://doi. org/10.1097/MED.0b013e3283339051)

11 Holst JJ. On the physiology of GIP and GLP-1. Hormone and Metabolic Research 200436 747-754.

12 Holst JJ, Windelov JA, Boer GA, Pedersen J, Svendsen B, Christensen M, Toreskov S, Asmar M, Hartmann B \& Nissen A. Searching for the physiological role of glucose-dependent insulinotropic polypeptide. Journal of Diabetes Investigation 20167 (Supplement 1) 8-12. (https://doi.org/10.1111/jdi.12488)

13 Asmar M, Simonsen L, Arngrim N, Holst JJ, Dela F \& Bulow J. Glucose-dependent insulinotropic polypeptide has impaired effect on abdominal, subcutaneous adipose tissue metabolism in obese subjects. International Journal of Obesity 201438 259-265.

14 Asmar M, Asmar A, Simonsen L, Gasbjerg LS, Sparre-Ulrich AH, Rosenkilde MM, Hartmann B, Dela F, Holst JJ \& Bulow J. The glucoand liporegulatory and vasodilatory effects of glucose-dependent insulinotropic polypeptide (GIP) are abolished by an antagonist of the human GIP receptor. Diabetes 201766 2363-2371. (https://doi. org/10.2337/db17-0480)

15 Tobin L, Simonsen L \& Bulow J. Real-time contrast-enhanced ultrasound determination of microvascular blood volume in abdominal subcutaneous adipose tissue in man. Evidence for adipose tissue capillary recruitment. Clinical Physiology and Functional Imaging 201030 447-452. (https://doi.org/10.1111/j.1475097X.2010.00964.X)

16 Mulder AH, van Dijk AP, Smits P \& Tack CJ. Real-time contrast imaging: a new method to monitor capillary recruitment in human forearm skeletal muscle. Microcirculation 200815 203-213. (https:// doi.org/10.1080/10739680701610681)

17 Simonsen L, Enevoldsen LH \& Bulow J. Determination of adipose tissue blood flow with local 133Xe clearance. Evaluation of a new labelling technique. Clinical Physiology and Functional Imaging 2003 23 320-323. (https://doi.org/10.1046/j.1475-0961.2003.00509.x)

18 Lindgren O, Carr RD, Deacon CF, Holst JJ, Pacini G, Mari A \& Ahren B. Incretin hormone and insulin responses to oral versus intravenous lipid administration in humans. Journal of Clinical Endocrinology and Metabolism 201196 2519-2524. (https://doi. org/10.1210/jc.2011-0266)

19 Dawson D, Vincent MA, Barrett EJ, Kaul S, Clark A, Leong-Poi H \& Lindner JR. Vascular recruitment in skeletal muscle during exercise and hyperinsulinemia assessed by contrast ultrasound. American Journal of Physiology: Endocrinology and Metabolism 2002282 E714-E720. (https://doi.org/10.1152/ajpendo.00373.2001)

20 Vincent MA, Dawson D, Clark AD, Lindner JR, Rattigan S, Clark MG \& Barret EJ. Skeletal muscle microvascular recruitment by physiological hyperinsulinemia precedes increases in total blood flow. Diabetes 200251 42-48. (https://doi.org/10.2337/ diabetes.51.1.42)

21 Vincent MA, Clerk LH, Lindner JR, Klibanov AL, Clark MG, Rattigan S \& Barret EJ. Microvascular recruitment is an early insulin effect that regulates skeletal muscle glucose uptake in vivo. Diabetes 200453 1418-1423. (https://doi.org/10.2337/diabetes.53.6.1418)

22 Gersh I \& Still MA. Blood vessels in fat tissue. Relation to problems of gas exchange. Journal of Experimental Medicine 194581 219-232.

23 Sotornik R, Brassard P, Martin E, Yale P, Carpentier AC \& Ardilouze JL. Update on adipose tissue blood flow regulation. American Journal of Physiology: Endocrinology and Metabolism 2012302 E1157-E1170. (https://doi.org/10.1152/ajpendo.00351.2011)

24 Summers LK, Samra JS, Humphreys SM, Morris RJ \& Frayn KN. Subcutaneous abdominal adipose tissue blood flow: variation within and between subjects and relationship to obesity. Clinical Science 199691 679-683. (https://doi.org/10.1042/cs0910679) 
25 Hjemdahl P, Akerstedt T, Pollare T \& Gillberg M. Influence of betaadrenoceptor blockade by metoprolol and propranolol on plasma concentrations and effects of noradrenaline and adrenaline during i.v. infusion. Acta Physiologica Scandinavica: Supplementum 1983515 45-53.

26 Tobin L, Simonsen L, Galbo H \& Bulow J. Vascular and metabolic effects of adrenaline in adipose tissue in type 2 diabetes. Nutrition and Diabetes 20122 e46. (https://doi.org/10.1038/nutd.2012.19)

27 Barrett EJ, Eggleston EM, Inyard AC, Wang H, Li G, Chai W \& Liu Z. The vascular actions of insulin control its delivery to muscle and regulate the rate-limiting step in skeletal muscle insulin action. Diabetologia 2009 52 752-764. (https://doi.org/10.1007/s00125-009-1313-z)

28 Clark MG, Wallis MG, Barrett EJ, Vincent MA, Richards SM, Clerk LH $\&$ Rattigan S. Blood flow and muscle metabolism: a focus on insulin action. American Journal of Physiology: Endocrinology and Metabolism 2003284 E241-E258. (https://doi.org/10.1152/ajpendo.00408.2002)

29 Zhang L, Vincent MA, Richards SM, Clerk LH, Rattigan S, Clark MG \& Barret EJ. Insulin sensitivity of muscle capillary recruitment in vivo. Diabetes 200453 447-453. (https://doi.org/10.2337/diabetes.53.2.447)

30 Baron AD. Hemodynamic actions of insulin. American Journal of Physiology 1994267 E187-E202. (https://doi.org/10.1152/ ajpendo.1994.267.2.E187)

31 Vincent MA, Barrett EJ, Lindner JR, Clark MG \& Rattigan S. Inhibiting NOS blocks microvascular recruitment and blunts muscle glucose uptake in response to insulin. American Journal of Physiology: Endocrinology and Metabolism 2003285 E123-E129. (https://doi. org/10.1152/ajpendo.00021.2003)

32 Moncada S \& Higgs EA. Nitric oxide and the vascular endothelium. Handbook of Experimental Pharmacology 2006176 213-254.
33 Ding KH, Zhong Q, Xu J \& Isales CM. Glucose-dependent insulinotropic peptide: differential effects on hepatic artery vs. portal vein endothelial cells. American Journal of Physiology: Endocrinology and Metabolism 2004286 E773-E779. (https://doi.org/10.1152/ ajpendo.00507.2003)

34 Rudovich N, Kaiser S, Engeli S, Osterhoff M, Gogebakan O, Bluher M $\&$ Pfeiffer AF. GIP receptor mRNA expression in different fat tissue depots in postmenopausal non-diabetic women. Regulatory Peptides 2007142 138-145. (https://doi.org/10.1016/j.regpep.2007.02.006)

35 Ahlqvist E, Osmark P, Kuulasmaa T, Pilgaard K, Omar B, Brons C, Kotova O, Zetterqvist AV, Stancakova A, Jonsson A, et al. Link between GIP and osteopontin in adipose tissue and insulin resistance. Diabetes 201362 2088-2094. (https://doi.org/10.2337/ db12-0976)

36 Ceperuelo-Mallafre V, Duran X, Pachon G, Roche K, GarridoSanchez L, Vilarrasa N, Tinahones FJ, Vicente V, Pujol J, Vendrell J, et al. Disruption of GIP/GIPR axis in human adipose tissue is linked to obesity and insulin resistance. Journal of Clinical Endocrinology and Metabolism 201499 E908-E919. (https://doi.org/10.1210/jc.20133350)

37 Asmar A, Asmar M, Simonsen L, Madsbad S, Holst JJ, Hartmann B, Soerensen CM \& Bulow J. Glucagon-like peptide-1 elicits vasodilation in adipose tissue and skeletal muscle in healthy men. Physiological Reports 20175 e13073. (https://doi.org/10.14814/phy2.13073)

38 Sjoberg KA, Holst JJ, Rattigan S, Richter EA \& Kiens B. GLP-1 increases microvascular recruitment but not glucose uptake in human and rat skeletal muscle. American Journal of Physiology: Endocrinology and Metabolism 2014306 E355-E362. (https://doi. org/10.1152/ajpendo.00283.2013)

Received in final form 1 May 2019 Accepted 7 May 2019 (c) 2019 The authors Published by Bioscientifica Ltd
This work is licensed under a Creative Commons Attribution-NonCommercial-NoDerivatives 4.0 Internationab sicense.ifica . com at 04/26/2023 01:31:29PM 